\title{
A thermodynamic investigation of barium and calcium sulfate stability in sediments at an oceanic ridge axis (Juan de Fuca, ODP legs 139 and 169)
}

\author{
Christophe Monnin, ${ }^{1, *}$ Sabine Balleur, ${ }^{2,3}$ and Bruno Goffe ${ }^{2}$ \\ ${ }^{1}$ CNRS/Université Paul Sabatier, Laboratoire Mécanismes de Transfert en Géologie, 38 rue des Trente Six Ponts, 31400 Toulouse, France \\ ${ }^{2}$ CNRS/Ecole Normale Supérieure, Laboratoire de Géologie, 24 rue Lhomond, 75005 Paris, France \\ ${ }^{3}$ Etudes et Production Schlumberger, 1 rue Henri Bequerel, 92140 Clamart, France
}

(Received March 14, 2002; accepted in revised form January 27, 2003)

\begin{abstract}
We have used a new thermodynamic model of barium and calcium sulfate solubilities in multicomponent electrolyte solutions (Monnin, 1999) to investigate the stabilities of barite and anhydrite in seawater or in marine sediment porewaters at high temperature and pressure. As a further test supplementing those previously carried out during model development, we have calculated the temperature at which standard seawater becomes saturated with respect to anhydrite. The model predicts that, upon heating at 500 bars, standard seawater becomes saturated with respect to anhydrite at $147 \pm 5^{\circ} \mathrm{C}$, which compares well with the literature value of $150^{\circ} \mathrm{C}$ (Bishoff and Seyfried, 1978). At 20 bars the calculated saturation temperature is 117 $\pm 3^{\circ} \mathrm{C}$. This points to a non negligible pressure effect even at moderate pressures.

We have calculated the barite and anhydrite saturation indices for the in situ temperatures and pressures, from the composition of porewaters collected at ODP Sites 855, 856, 857, 858, 1035 and 1036 during ODP Legs 139 and 169 (Juan de Fuca and Gorda ridges, NE Pacific). Calculated saturation indices for porewater samples collected at depths corresponding to temperatures between $70^{\circ}$ and $110-120^{\circ} \mathrm{C}$ at an in situ pressure of about 260 bars yield equilibrium values for anhydrite and barite. Saturation indices of samples collected at depths where the temperature exceeds $110-120^{\circ} \mathrm{C}$, however, yield values indicating supersaturation with respect to anhydrite and undersaturation with respect to barite. This result is consistent with the redissolution of anhydrite during cooling, leading to the well documented sampling artifact affecting porewater compositions in high temperature marine sediments: anhydrite dissolution increases the porewater sulfate content, which in turn induces a loss of barium from solution through barite precipitation (the common ion effect). We postulate that this redissolution occurs in sediment samples for which the in situ temperature exceeds $110-120^{\circ} \mathrm{C}$ : below this limit anhydrite remains at equilibrium or does not have time to significantly dissolve before porewaters are sampled. Copyright (C) 2003 Elsevier Ltd
\end{abstract}

\section{INTRODUCTION}

Anhydrite is commonly found in high temperature oceanic environments linked to hydrothermal activity at spreading centers (Chang et al., 1996). Its occurrence is reported in altered sediments and mineral deposits forming at ridge axis, such as the Juan de Fuca ridge (NE Pacific), which has been the target of two drilling legs (139 and 169) of the Ocean Drilling Program (Davis et al., 1992; Fouquet et al., 1998). In the laboratory, anhydrite solubility in aqueous solutions is well documented by numerous measurements at various temperatures and pressures which showed that its solubility decreases when temperature increases. This body of experimental data has been summarized and critically evaluated in the recent development of solubility models based on Pitzer's ion interaction formalism (Harvie et al., 1984; Greenberg and Moller, 1989; Monnin, 1990). Such models which are for now limited to temperatures of about $200^{\circ} \mathrm{C}$ and to pressures up to $1 \mathrm{kbar}$, allow the calculation of mineral solubilities in a large range of concentration and composition, including seawater-type solutions. Due to its retrograde solubility, anhydrite precipitates when seawater is heated. Using her model of the $\mathrm{Na}-\mathrm{Ca}-\mathrm{Cl}-$ $\mathrm{SO} 4-\mathrm{H}_{2} \mathrm{O}$ system as a thermodynamic model for standard seawater, Moller (1988) has calculated that standard seawater

* Author to whom correspondence should be addressed (monnin@ lmtg.ups-tlse.fr). reaches equilibrium with anhydrite at $108^{\circ} \mathrm{C}$ at water vapor saturation pressure. On another hand, Bischoff and Seyfried (1978) experiments show that the seawater-anhydrite equilibrium temperature is $150^{\circ} \mathrm{C}$ at 500 bars.

When present in oceanic sediments, anhydrite is likely to dissolve when high temperature hydrothermal fluids cool down during mixing with low-temperature fluids linked to off-axis circulation (Sleep, 1991). Conversely, it may precipitate when seawater is heated in downwelling or recharge zones. Anhydrite precipitation may then clog the porosity and hence affect the flow geometry and the depth to which hydrothermal fluids may penetrate the crust, as extensively discussed by Sleep (1991). Anhydrite will also dissolve when sediment cores brought back to the surface cool down. This may then lead to high porewater calcium and sulfate concentrations that look anomalous when compared to those normally encountered in marine environments. This sampling artifact has been invoked to explain $\mathrm{Ca}$ and $\mathrm{SO}_{4}$ concentrations of porewaters from sediment cores recovered at ODP Sites 856 and 1035 drilled during ODP Legs 139 and 169 at the Dead Dog and Bent Hill areas of the Juan de Fuca Ridge (Davis et al., 1992; Fouquet et al., 1998). In addition, high porewater calcium and sulfate concentrations at ODP Site 856 have been attributed to an in-situ natural cause, i.e., present day in-situ dissolution of anhydrite deposited when sediment temperatures were higher due to sill intrusions (Davis et al., 1992). In another environ- 

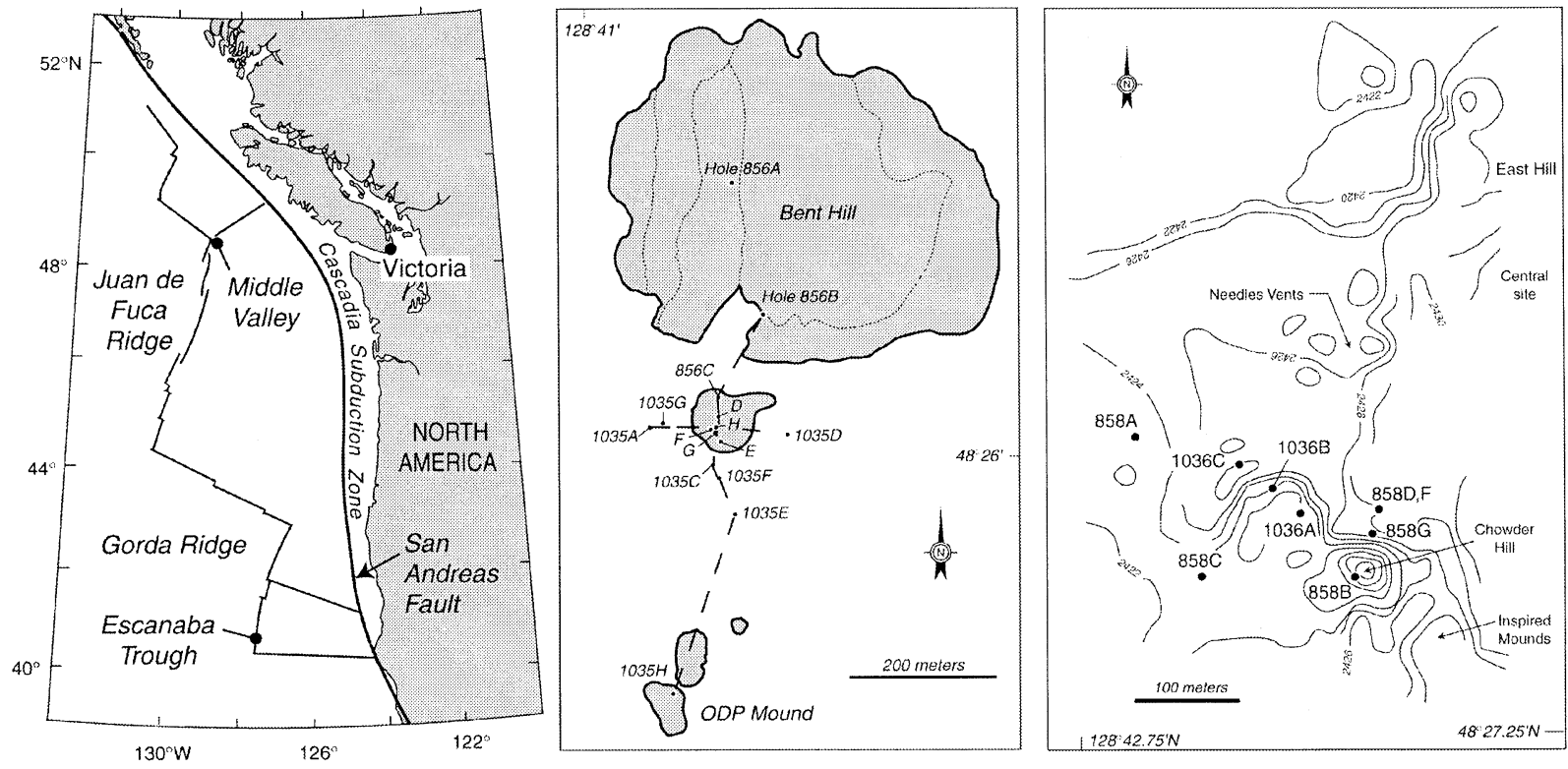

Fig. 1. (a) A map of the North-East Pacific ridge showing the locations of Middle Valley and Escabana Trough on the Juan de Fuca and Gorda spreading centers (after Fouquet et al., 1998); location of ODP boreholes in (b) the Bent Hill area and (c) the Dead Dog Mound area of Middle Valley.

ment, the stability of anhydrite in contact with the Red Sea brines has been investigated by Monnin and Ramboz (1996) and by Anschutz et al. (2000).

Another common sulfate found in the marine environment is barite (barium sulfate). Its occurrence is widespread in suspended matter in the water column of the oceans where its formation is linked to biologic activity (Dehairs et al., 1980; Hanor, 2000). It accumulates on the seafloor as micrometerscale crystals during sedimentation. In oceanic hydrothermal environments, barite is an important constituent of hydrothermal chimneys and mounds (Chang et al., 1996; Hanor, 2000). Barium sulfate solubility has also been extensively investigated by laboratory experiments. In aqueous solutions containing less than $0.25 \mathrm{M} \mathrm{NaCl}$, barite solubility increases with temperature up to $150^{\circ} \mathrm{C}$, then it decreases above this temperature. This solubility maximum is not observed for more concentrated solutions (Blount, 1977). Barite solubilities in various aqueous solutions have recently been used to construct a solubility model as a function of temperature, pressure and solution composition to $200^{\circ} \mathrm{C}$ and to $1 \mathrm{kbar}$ (Monnin, 1999).

For a given temperature and pressure, the stability of solid sulfates in the marine environment will depend on the concentrations of sulfate and of the constituent cation in the porewaters. The sulfate concentration can decrease, either by bacterial sulfate reduction at low temperatures (below about $110^{\circ} \mathrm{C}$ ) or by thermal sulfate reduction (above about $125^{\circ} \mathrm{C}$ ). The decrease of the porewater sulfate content may induce redissolution of solid sulfates. This has been well documented for barite, leading to so-called barium remobilization (e.g., McManus et al., 1994; Torres et al., 1996; Monnin et al., 2000).

Up to now the stability of sulfate minerals in the marine environment has been inferred either from petrographic observations, or from changes in porewater compositions. In this paper, we use a recent model of alkaline earth sulfate solubilities in complex electrolyte solutions as a function of temper- ature, pressure and solution composition (Monnin, 1999) to investigate the stability of $\mathrm{Ca}, \mathrm{Sr}$ and $\mathrm{Ba}$ sulfates in sediments collected at a sedimented ridge axis (Juan de Fuca Middle Valley, ODP Leg 139 and Gorda Ridge Escabana Trough, ODP Leg 169).

\section{IN SITU BOREHOLE TEMPERATURES AT MIDDLE VALLEY AND ESCANABA TROUGH}

Middle Valley and Escanaba Trough are two sections of the Pacific ridge situated respectively at the northernmost section of the Juan de Fuca ridge and at the southern end of the Gorda ridge (Fig. 1). Because of the proximity of the North American continental margin, Middle Valley and Escabana Trough have been rapidly filled over geologic times by terrigenous sediments consisting of turbidite units of variable thickness, irregularly interbedded with biogenic pelagic sediments. Active discharge of high temperature fluids through these sediments has lead to the formation of large massive sulfide deposits which have been the targets of ODP Legs 139 and 169 (Davis et al., 1992; Fouquet et al., 1998). Cores and hydrothermal fluids have been collected in holes drilled at sites of active hydrothermal discharge. Thermal gradients at these locations can be very large and range from $0.34^{\circ} \mathrm{C} / \mathrm{m}$ for Hole 855 , to $3^{\circ} \mathrm{C} / \mathrm{m}$ for Holes $858 \mathrm{C}$ (Table 1 ). For the present calculations, we have either used the temperature gradients given in the Initial Reports of Legs 139 and 169 or, when these are not given, we have fitted the reported temperature data to polynomials (Table 1). For all the studied sites we have used a bottom seawater temperature of $1.8^{\circ} \mathrm{C}$ (Davis and Villinger, 1992). A very detailed analysis of temperature measurements is required to detect an eventual curvature in the temperature-depth profile that can be the sign of a local heat transport by fluid advection (Davis and Villinger, 1992). Temperatures needed for the thermodynamic calculations need not be as accurate as those required by the thermal analysis. 
Table 1. Temperature-depth relationships used for the saturation index calculations for ODP leg 139 and 169 boreholes.

\begin{tabular}{|c|c|c|}
\hline Hole & Temperature vs. depth & Reference \\
\hline \multicolumn{3}{|l|}{ ODP Leg 139} \\
\hline $855 \mathrm{~A}, \mathrm{~B}$ and $\mathrm{C}$ & $1.8+0.328 \mathrm{z}$ & Mottl et al., 1992, p. 160 \\
\hline $856 \mathrm{~A}$ & $1.8+0.50 \mathrm{z}$ & Mottl et al., 1992, p. 279 \\
\hline $856 \mathrm{~B}$ & $1.8+1.27 \mathrm{z}$ & Mottl et al., 1992, p. 279 \\
\hline $857 \mathrm{~A}$ and $\mathrm{B}$ & $1.8+0.612 \mathrm{z}$ & Mottl et al., 1992, p. 410 \\
\hline $858 \mathrm{~A}$ & $1.8+1.70 \mathrm{z}$ & This work \\
\hline $858 \mathrm{C}$ & $1.8+2.95 \mathrm{z}$ & This work \\
\hline \multicolumn{3}{|l|}{ ODP Leg 169} \\
\hline $1035 \mathrm{~A}$ & $\begin{array}{l}1.8+1.44 \mathrm{z} \text { for } 0<\mathrm{z}<36 \\
22.5+.858 \mathrm{z} \text { for } \mathrm{z}>36 \mathrm{mbsf}\end{array}$ & This work \\
\hline $1035 \mathrm{D}$ & $1.8+2.197 \mathrm{z}$ & This work \\
\hline $1035 \mathrm{E}$ & $\begin{array}{l}1.8+2.011 \mathrm{z} \text { for } 0<\mathrm{z}<26 \\
15.389+1.498 \mathrm{z} \text { for } \mathrm{z}>26 \mathrm{mbsf}\end{array}$ & This work \\
\hline $1036 \mathrm{~A}, \mathrm{~B}$ and $\mathrm{C}$ & $1.8+5.078 \mathrm{z}-0.0468 \mathrm{z}^{2}$ & This work \\
\hline 1037 & $1.8+0.165 \mathrm{z}$ & Fouquet et al., 1998, p. 233 \\
\hline
\end{tabular}

In situ temperature measurements were made at all sites, but at depths shallower than the maximum depth reached during drilling. Porewaters have be recovered at more regular intervals: typically one sample is taken in every $1.5 \mathrm{~m}$ segment of the first and last cores, and one sample is taken in every other core. In situ temperatures of the porewater samples collected at depths below the last temperature measurement must be calculated by extrapolating temperature-depth relationships outside the ranges of direct measurements. For example, Hole $858 \mathrm{C}$ has been drilled to $85 \mathrm{mbsf}$ and porewater samples collected to this depth, but temperatures have been measured to $43 \mathrm{mbsf}$ only. At Sites 1035, 1036 and 1038, the data show that the thermal regime is not purely conductive. This leads to nonlinear variations of temperature with depth, and therefore to uncertainties in extrapolated temperatures. For example, assuming a linear temperature variation with depth leads to estimate the temperature of the lowermost porewater sample $139-858 \mathrm{C}-\mathrm{IW} 16$ at $84.1 \mathrm{mbsf}$ to be $234^{\circ} \mathrm{C}$, while a quadratic fit to the temperature data gives $207^{\circ} \mathrm{C}$. This difference in temperature leads to a $20 \%$ difference in the anhydrite saturation index for this sample $\left(3.9\right.$ for $234^{\circ} \mathrm{C}$ and 3.1 for $\left.207^{\circ} \mathrm{C}\right)$. As we show below this cannot solely account for the deviation from equilibrium between porewaters and anhydrite.

Temperatures at Hole 1038I have been measured to $60 \mathrm{mbsf}$ showing a linear temperature gradient of $2^{\circ} \mathrm{C} / \mathrm{m}$ (Fouquet et al., 1998). The hole depth is $402 \mathrm{~m}$. Assuming the same temperature gradient as for the upper section of the hole would lead to an unrealistic temperature of $800^{\circ} \mathrm{C}$ at the bottom of the hole. As only few porewater samples are available for Hole 1038I we did not consider this hole any further.

\section{CALCUlation OF THE Ba, Sr AND Ca SUlFATE SATURATION INDICES FROM THE POREWATER COMPOSITIONS}

A mineral saturation index is defined here as the ratio of $\mathrm{Q}$, the ionic product of the considered mineral, to its solubility product $\mathrm{K}_{\mathrm{sp}}$ :

$$
\mathrm{SI}=\mathrm{Q} / \mathrm{K}_{\mathrm{sp}}
$$

The ionic product $\mathrm{Q}$ of a $\mathrm{MSO}_{4}$ mineral is defined as:

$$
\mathrm{Q}=\mathrm{m}_{\mathrm{M}^{2+}(\mathrm{aq}), \mathrm{T}} \cdot \mathrm{m}_{\mathrm{SO}_{4}^{2-}(\mathrm{aq}), \mathrm{T}} \cdot \gamma_{\mathrm{MSO}_{4(\mathrm{aq}), \mathrm{T}}^{2}}
$$

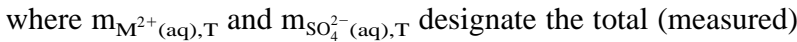
cation and sulfate molalities and $\gamma_{\mathrm{MSO}_{4}(\mathrm{aq}), \mathrm{T}}$ the total (or stoichiometric) activity coefficient of the aqueous electrolyte.

Pitzer's ion interaction formalism has allowed recent advances in the modeling of aqueous solutions and the construction of accurate solubility models of great importance for the earth sciences. Following the pioneering work of Harvie et al. (1984) at $25^{\circ} \mathrm{C}$, extension of such solubility models to high temperatures and pressures was undertaken (Pabalan and Pitzer, 1987; Greenberg and Moller, 1989; Monnin, 1989, $1990,1999)$. In the present work, we have used a new thermodynamic model for the Na-K-Ca-Mg-Ba-Sr-Cl- $-\mathrm{SO}_{4}-\mathrm{H}_{2} \mathrm{O}$ system (Monnin, 1999) to investigate mineral stabilities (mainly sulfates) through the calculation, from the porewater compositions and from the in situ temperature and pressures, of the mineral solubility products, of the activity coefficients of the aqueous solutes, and finally of the mineral saturation indices $\mathrm{Q} / \mathrm{K}_{\mathrm{sp}}$. The model that we use includes parts of the high temperature models of Greenberg and Moller (1989) for the $\mathrm{Na}-\mathrm{K}-\mathrm{Ca}-\mathrm{Cl}-\mathrm{SO}_{4}-\mathrm{H}_{2} \mathrm{O}$ system and of Pabalan and Pitzer (1987) for the $\mathrm{Na}-\mathrm{K}-\mathrm{Mg}-\mathrm{Cl}-\mathrm{SO}_{4}-\mathrm{H}_{2} \mathrm{O}$ system, and as such allows an accurate calculation of anhydrite and gypsum solubilities (see Monnin, 1999 for a discussion of parameter consistency). It takes into account pressure effects on mineral solubilities through the calculation of mineral solubility products and solute activity coefficients as a function of pressure (Monnin, 1989, 1990). It was found from anhydrite solubility data in $\mathrm{NaCl}$ solutions, that compressibility effects on the variation of solute activity coefficients with pressure are negligible at moderate pressures (up to 500 bars) or for moderately concentrated solutions (Monnin, 1990). Systematic comparison between predicted mineral solubilities and values measured in aqueous solutions not used in model parameterization allowed to estimate a conservative model uncertainty in mineral solubility calculations of about $10 \%$, although solubilities are usually predicted within experimental error (Weare, 1987; Monnin, 1999). This translates into a saturation index range between 0.9 and 1.1 within which equilibrium is assumed to be reached. Whereas this criterion proved adequate to depict barite 


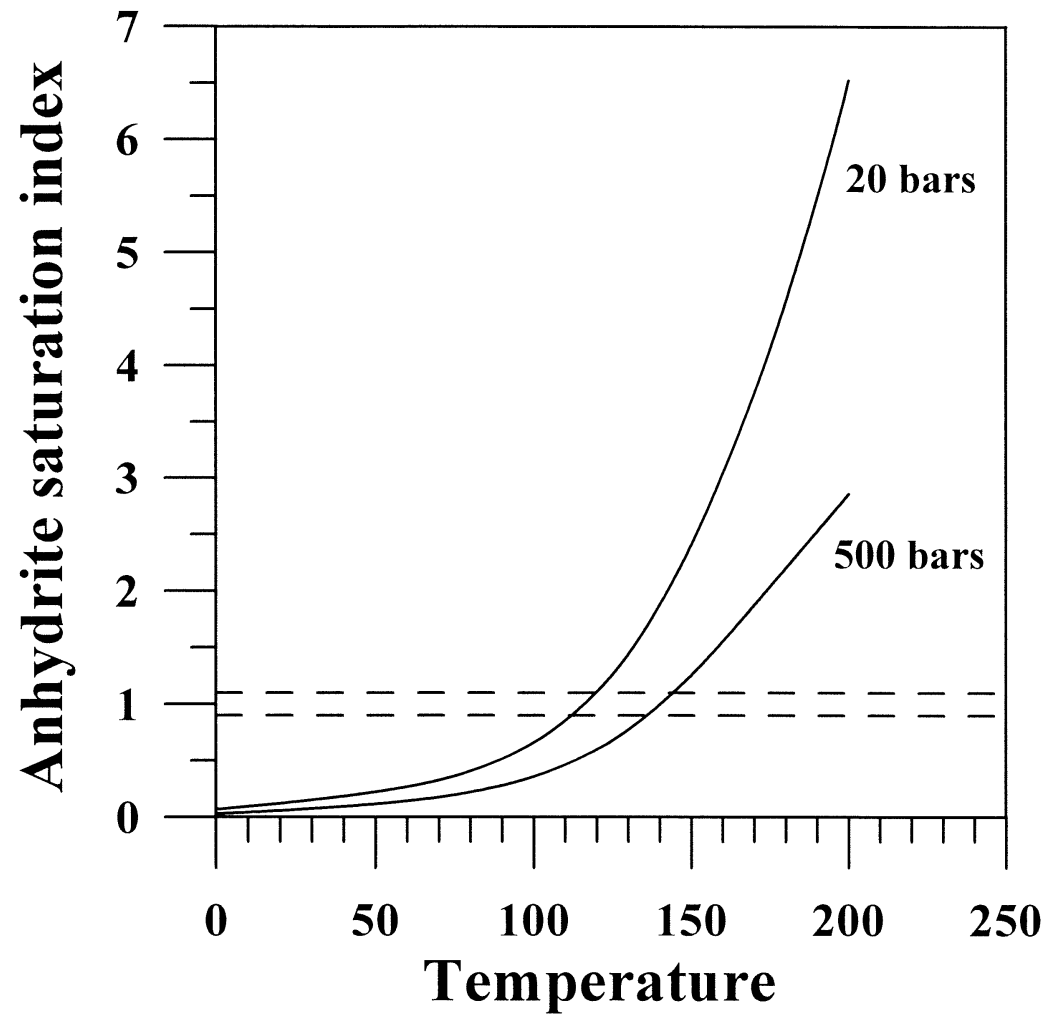

Fig. 2. The variation of the anhydrite saturation index for standard seawater versus temperature at the indicated pressure. The dashed lines delimitate the saturation index range within which equilibrium is assumed.

equilibrium in open ocean waters (Monnin et al., 1999), it has been found too stringent for oceanic sediment porewaters due to the scatter in the data (Monnin et al., 2000). For these reasons, Monnin et al. (2000) suggested that equilibrium between barite and sediment porewaters was reached when the barite saturation index lay between 0.5 and 1.5.

As a further test of model performance, we have calculated the anhydrite saturation index of standard seawater as a function of temperature at pressures of 20 bars and 500 bars (Fig. 2). We find that, upon heating, standard seawater reaches equilibrium with anhydrite at $117 \pm 3^{\circ} \mathrm{C}$ at 20 bars and $143 \pm$ $5^{\circ} \mathrm{C}$ at 500 bars (the uncertainties are calculated assuming equilibrium for $\mathrm{SI}=1.0 \pm 0.1$ ). The value at 20 bars is in accordance with Moller (1988) who found an equilibrium temperature of $108^{\circ} \mathrm{C}$, when the $\mathrm{Na}-\mathrm{Ca}-\mathrm{Cl}-\mathrm{SO}_{4}-\mathrm{H}_{2} \mathrm{O}$ system is used as a model for anhydrite solubility in seawater. Our result at 500 bars is also in good agreement with the experimental value of Bischoff and Seyfried (1978), especially if we note that Bischoff and Seyfried have obtained their estimate of the temperature at which seawater is at equilibrium with anhydrite, by interpolating loosely spaced measurements at 75,150 and $200^{\circ} \mathrm{C}$.

\section{APPLICATION: BARITE AND ANHYDRITE STABILITIES IN HIGH TEMPERATURE MARINE SEDIMENTS}

During ODP Leg 139 and 169, most porewaters have been retrieved by sediment squeezing following the usual ODP procedure. Porewater samples of indurated sediments obtained by the GRIND technique (Wheat et al., 1994) did not show any difference in composition with those obtained by squeezing. Major element concentrations are reported in the ODP Leg 139 (Davis et al., 1992) and Leg 169 Initial Report volumes (Fouquet et al., 1998), while Ba data for Leg 139 (Sites 855 to 858) are reported by Wheat and Mottl (1994). The barium contents of the ODP leg 169 porewater samples were not available at the time of this work.

To illustrate the variation of the dissolved element concentrations in porewaters, Figure 3 depicts the $\mathrm{Ca}, \mathrm{SO}_{4}, \mathrm{Ba}$ and $\mathrm{Sr}$ concentration profiles for Holes 857A and 857C (Davis et al., 1992; Wheat and Mottl, 1994). One can see that the sulfate concentration decreases with depth down the holes while $\mathrm{Ca}$ and $\mathrm{Sr}$ exhibit parallel increasing trends. Barium in porewaters also increases, but the data are very scattered. One can refer to the ODP Leg 139 (Davis et al., 1992) and Leg 169 Initial Report volumes (Fouquet et al., 1998), to Wheat and Mottl (1994) and to Gieskes et al. (2002) for a complete description of the porewater compositions.

Our calculations first show that all porewaters are largely undersaturated with respect to gypsum, anhydrite or celestite and markedly supersaturated with respect to barite at the shipboard $\mathrm{T}$ and $\mathrm{P}$ conditions $\left(25^{\circ} \mathrm{C}\right.$ and 1 bar). No indication whatsoever of equilibration of the porewaters with these minerals at shipboard conditions could be found. Our calculations also indicate that gypsum and celestite are always undersaturated at the borehole in situ temperature and pressure. This is consistent with the fact that, as a hydrated phase, gypsum is stable only at low temperature and/or high water activities. The 

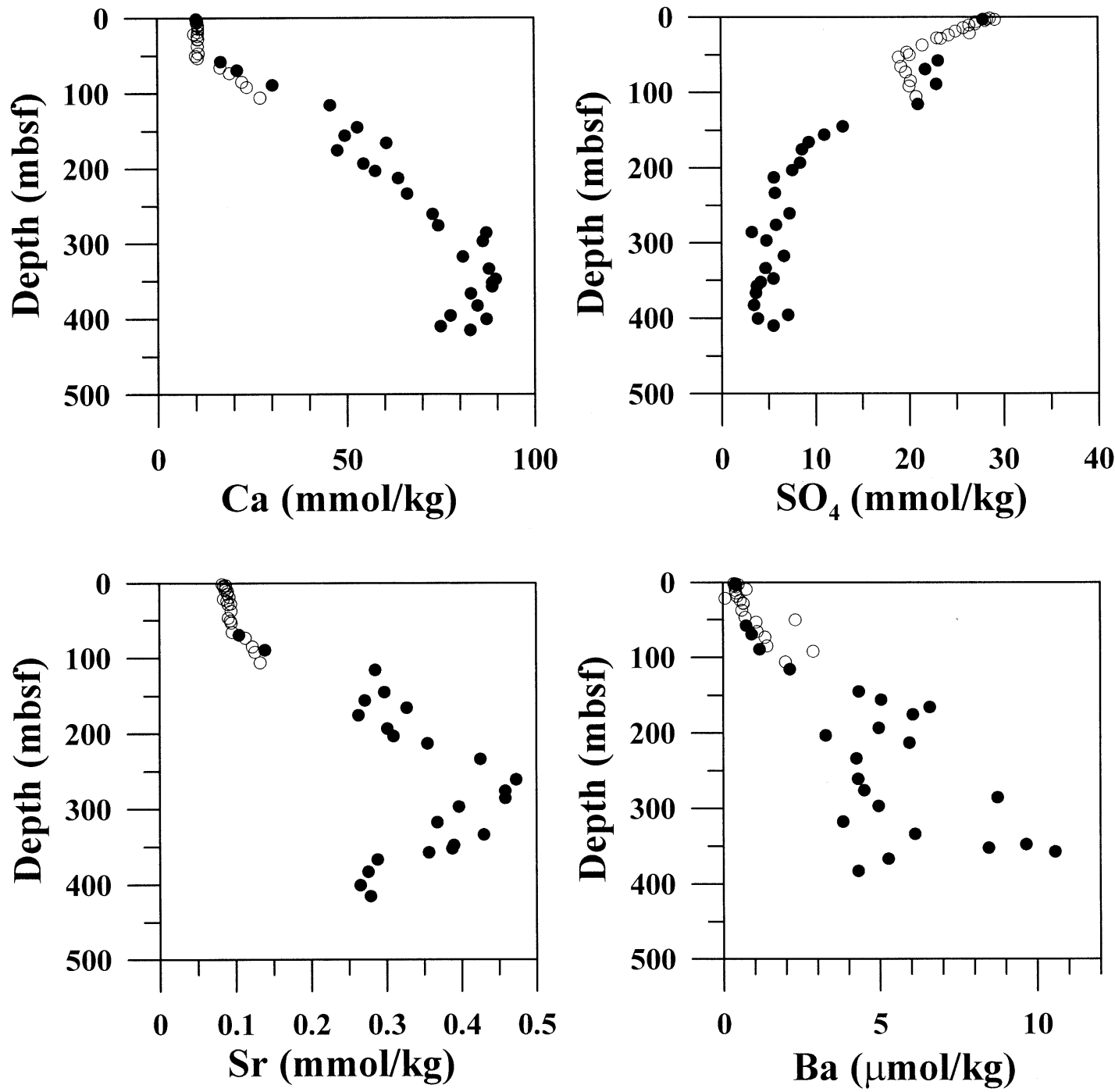

Fig. 3. $\mathrm{Ca}, \mathrm{Ba}, \mathrm{Sr}$ and $\mathrm{SO}_{4}$ concentration profiles in porewaters of Hole $857 \mathrm{~A}$ (open circles) and Hole $857 \mathrm{C}$ (filled circles).

occurrence of celestite in marine sediments is very rare and linked to peculiar conditions (Hanor, 2000). For example Baker and Bloomer (1988) have shown that dissolution of Sr-rich calcium carbonates can locally increase the Sr content of sediment porewaters in an environment where sulfate is not consumed by diagenesis and induce celestite precipitation. We thus discuss below results only for anhydrite and barite.

In Figure 4, we have reported the anhydrite saturation indices for all the studied sites versus temperature on one hand, and versus depth in the sediment on the other. When plotted versus depth, data sets for individual holes plot on distinct curves. When plotted versus temperature, the same data show a single trend, with a scatter larger in the supersaturation side that in the undersaturation side. This points to the fact that temperature is a main factor controlling the porewater saturation state, despite differences in lithology or sediment mineralogical composition that may exist at a given depth. In what follows, we have chosen to plot the results for each site versus temperature and not depth. Conversion from temperature to depth can be readily obtained with the relationships given in Table 1.

The seafloor at ODP Leg 139 and 169 Sites is at about $2600 \mathrm{~m}$ below sea level, i.e., 260 bars.

\subsection{Eastern Boundary of Middle Valley (ODP site 855)}

During Leg 139, four holes were drilled at this site to investigate the possibility that the eastern boundary fault bounding the eastern side of Juan de Fuca ridge is a conduit through which seawater penetrates basement. The sediment is composed of unaltered hemipelagic muds and turbidites and is considered to represent "an unaltered background" (Mottl et al., 1992; Kurnosov et al., 1994). Porewaters have a composition very similar to normal seawater. No sulfate reduction is reported (Mottl et al., 1992). Our results (Fig. 5) indicate that anhydrite is markedly undersaturated throughout the whole sediment column, consistently with the fact that no anhydrite 


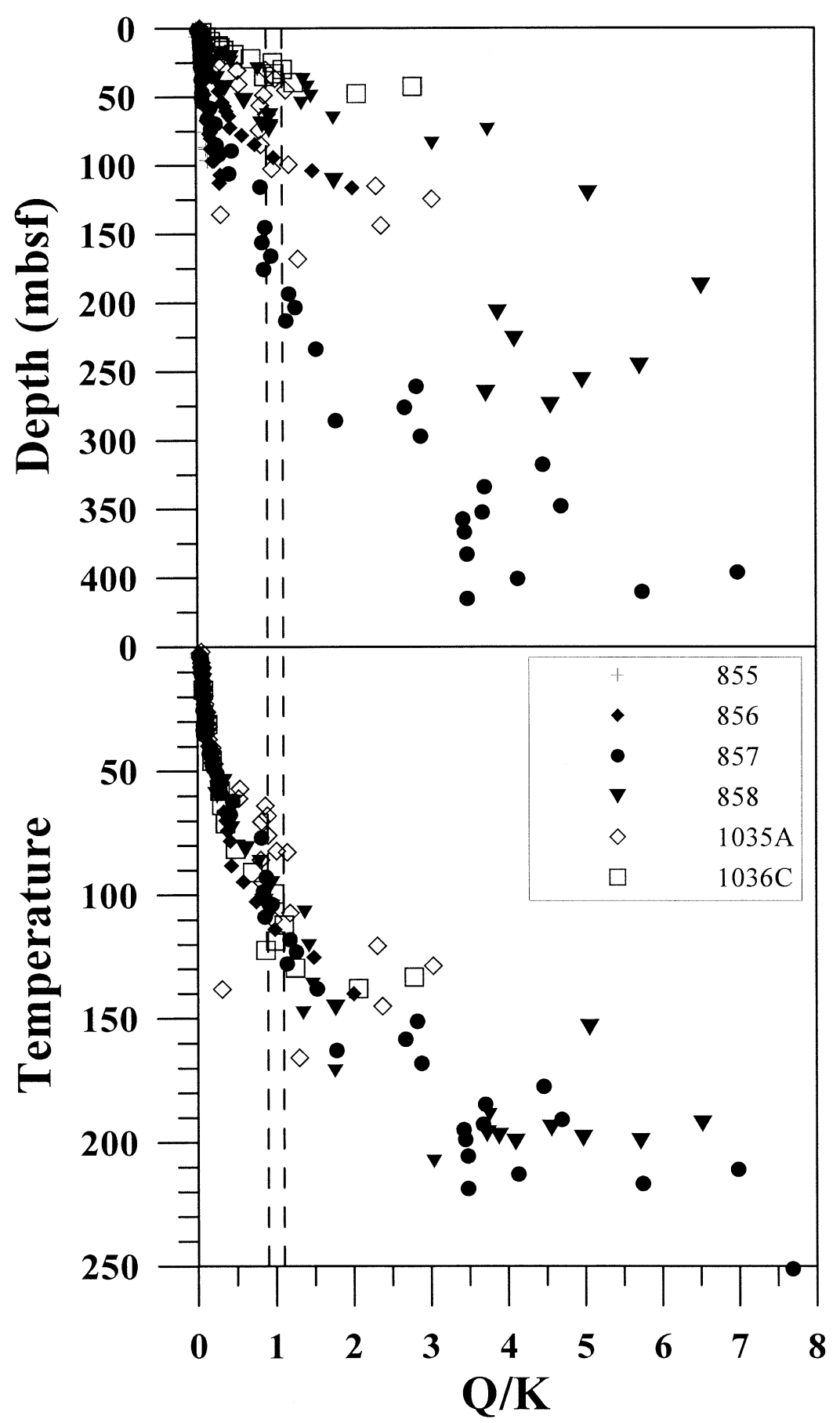

Fig. 4. The variation of the anhydrite saturation index for all the ODP Leg 139 and 169 sites studied in this work versus depth and versus in situ temperature. The dashed lines delimitate the saturation index range within which equilibrium is assumed.

has been found in the sediment. Barite is supersaturated in the upper part of the holes with a tendency toward equilibrium at depth. Note that the Northern Pacific Ocean bottom waters are at equilibrium with barite at this depth (Monnin et al., 1999). This barite supersaturation in the upper $20 \mathrm{~m}$ of the sediment column has already been observed for porewaters from sediments of the Eastern flank of the Juan de Fuca ridge (Monnin et al., 2000).

\subsection{Bent Hill Area}

During ODP Leg 139 (July-August 1991), two holes (856A and $856 \mathrm{~B})$ were drilled in a small hill called Bent Hill $(500 \mathrm{~m}$ in diameter and $60 \mathrm{~m}$ high) in the Eastern part of Middle Valley (Fig. 1). 100m south of this hill lies a smaller hill (35m high) hosting a large sulfide deposit (the Bent Hill Massive Sulfide deposit or BHMS) in which six holes were drilled (856C, 


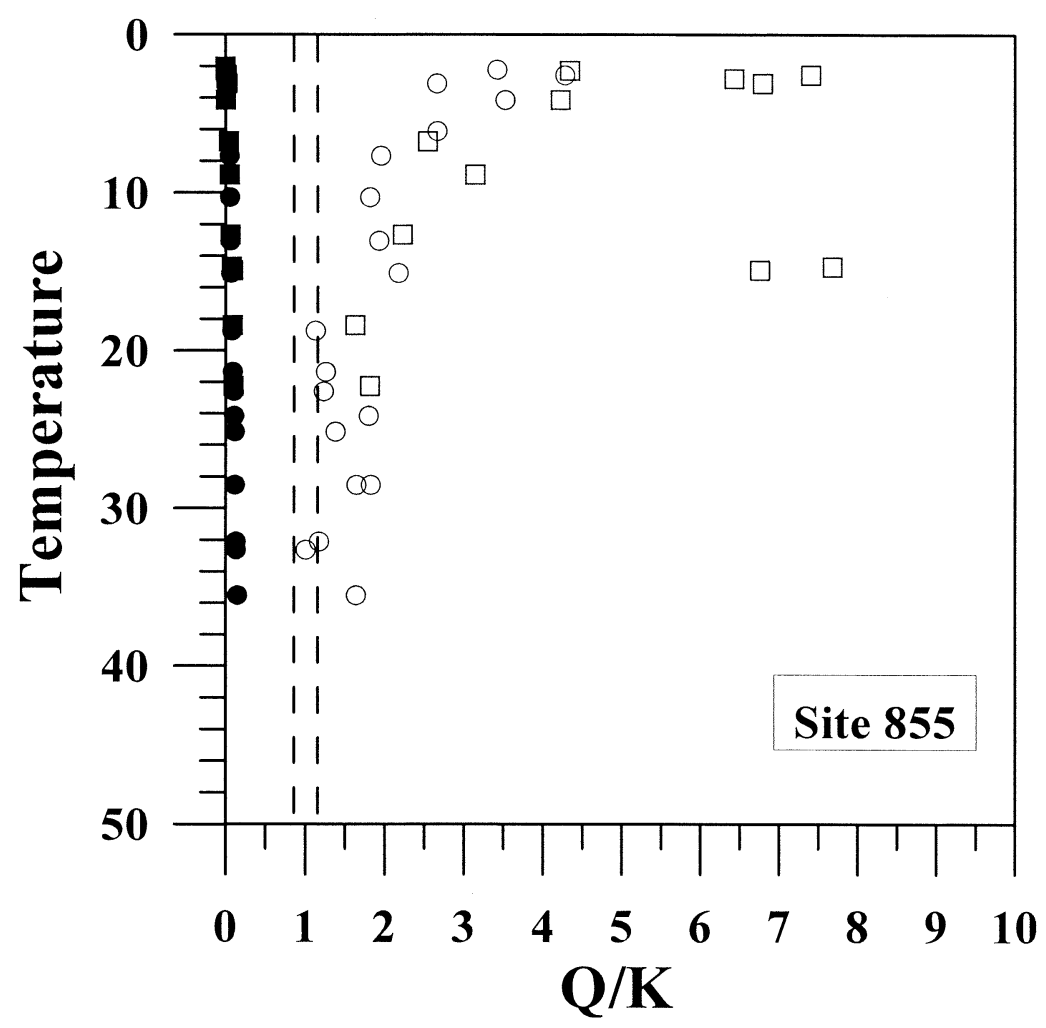

Fig. 5. The anhydrite (filled symbols) and barite (open symbols) saturation indices for porewaters of ODP Site 855 versus the in-situ temperature (squares: Hole 855A; circles: Hole 855C).

856D, 856E, 856F, 856G and 856H; Fig. 1). During Leg 169 (August-September 1996), eight more holes were drilled at the Bent Hill site to constrain the extent of the Bent Hill Massive Sulfide (BHMS) deposit. Holes 1035A, 1035G and 1035D (together with Hole $856 \mathrm{H}$ ), are located along a west-east transect crosscutting the BHMS deposit, while Holes 1035C, $1035 \mathrm{~F}, 1035 \mathrm{E}$ (along with $856 \mathrm{C}$ and $856 \mathrm{H}$ ) line up along a north-south cross section. Hole $1035 \mathrm{H}$ was an exploratory hole drilled in another sulfide deposit (ODP Mound) $300 \mathrm{~m}$ south of the BHMS deposit (Fig. 1).

Although these holes are close to each other, there are large variations in the sediment and porewater compositions forming large lateral concentration gradients. The occurrence of anhydrite and barite, either disseminated or in veins, is reported (Kurnosov et al., 1994; Mottl et al., 1994).

\subsection{Site 856}

Porewater concentration profiles have been obtained for only two holes (856A and B). Anhydrite reaches saturation for a temperature of $110-120^{\circ} \mathrm{C}$ for Hole $856 \mathrm{~B}$, i.e., for depths below $90 \mathrm{mbsf}$, and is undersaturated throughout the whole borehole 856A (Fig. 6). There is a large scatter in the barite saturation indices for the upper section of the holes at this site, for which we also observe supersaturation. Barite is at equilibrium for the lower section of Hole 856B for temperatures above $70^{\circ} \mathrm{C}$, corresponding to depths below about $60 \mathrm{mbsf}$. This is just above sills that intruded the sediments and have certainly played a major role in the thermal and chemical disturbance of the sediments. The consequences of the sill intrusions on anhydrite occurrence is discussed in detail by Mottl et al. (1994) and by Gieskes et al. (2002).

\subsection{Site 1035}

Anhydrite is undersaturated in all porewater samples but the lowermost one for Hole 1035E (Fig. 7). It is close to or at equilibrium at temperatures between 70 and $110^{\circ} \mathrm{C}$ for Holes 1035A and 1035D. Data extend beyond $100^{\circ} \mathrm{C}$ only for Hole $1035 \mathrm{~A}$ and the results show anhydrite supersaturation with a large scatter in the data (Fig. 7).

\subsection{Site 857}

This site is located away from discharge and recharge zones in a high heat flow area. Porewater concentration profiles have been collected for Holes 857A and C. Only a few samples are available for Hole 857B and have not been treated in this work. Porewater samples from lithified sediments and basement rocks have been obtained by the GRIND technique (Wheat et al., 1994) for Holes 857C and 857D at depths below about 400 mbsf. The thermal gradient (Table 1) has been obtained from measurements in the upper $100 \mathrm{~m}$ of the boreholes and cannot be used to calculate in-situ temperatures of the GRIND samples with confidence. These samples have then not been considered in the present work.

Different from holes at Sites 855 and 856, the sulfate content of porewaters at Site 857 decreases with depth to reach a 


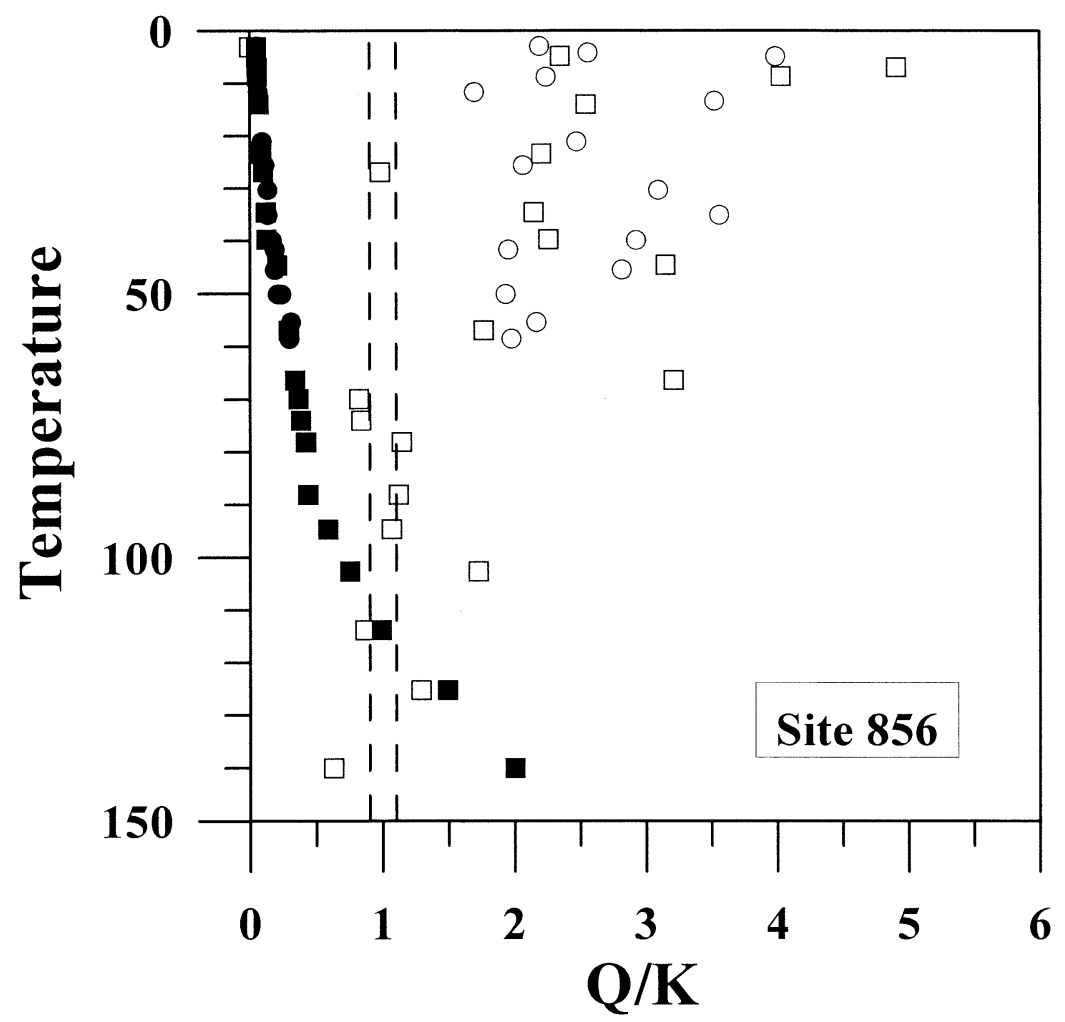

Fig. 6. The anhydrite (filled symbols) and barite (open symbols) saturation indices for porewaters of ODP Site 856 versus the in-situ temperature (squares: Hole 856A; circles: Hole 856B).

constant minimum value at about 200 mbsf, likely due to bacterial sulfate reduction at least in the upper part of the sediment column (Mottl et al., 1992). Alteration of silicates produces an increase in porewater $\mathrm{Ca}$ concentration and a decrease in Mg (Mottl et al., 1992, p. 317).

Our calculations (Fig. 8) show that porewaters are undersaturated with respect to anhydrite for temperatures below $70^{\circ} \mathrm{C}$ (i.e., about $100 \mathrm{mbsf}$ for Hole $857 \mathrm{C}$ ). They are at equilibrium for temperatures between 70 and about $110^{\circ} \mathrm{C}$ (between 100 and $170 \mathrm{mbsf}$ for Hole $857 \mathrm{C}$ ), and are supersaturated above (Fig. 8). As for Sites 855 and 856, barite is supersaturated for porewaters of the upper part of the sediment column. Its saturation index then decreases with depth: porewaters are at equilibrium with barite for temperatures between 30 and $110^{\circ} \mathrm{C}$. Above this temperature they become undersaturated as the same time when anhydrite becomes supersaturated

\subsection{Dead Dog Area}

The Dead Dog area is a site of active venting of hydrothermal fluids situated about $5 \mathrm{~km}$ northwest of the Bent Hill area in Middle Valley. Drilling at this location was intended to investigate the mechanisms of formation of sediment-covered mounds where the vents are located. Eight holes were drilled at Site 858 during ODP Leg 139 and three at Site 1036 during ODP leg 169 (Fig. 1).

\subsection{Site 858}

The sediments at Site 858 display large hydrothermal alteration, with common occurrence of anhydrite and barite (Kurn- osov et al., 1994). The variations of their saturation indices with temperature (Fig. 9) bear some resemblance with those for Site 857 (Dead Dog area). Anhydrite reaches saturation for a temperature of $90^{\circ} \mathrm{C}$ (about $60 \mathrm{mbsf}$ for Hole $858 \mathrm{~A}$ and $30 \mathrm{mbsf}$ for Hole $858 \mathrm{C}$ ) and is at equilibrium for temperatures between 90 and $110^{\circ} \mathrm{C}$ (about $80 \mathrm{mbsf}$ for Hole $858 \mathrm{~A}$ and $40 \mathrm{mbsf}$ for Hole $858 \mathrm{C})$. Porewaters are supersaturated above $110^{\circ} \mathrm{C}$.

The barite saturation index shows a behavior symmetrical to that of anhydrite. As for other sites, barite is first supersaturated. Its saturation index then decreases with depth to reach the equilibrium value for a temperature of about $90^{\circ} \mathrm{C}$. Barite becomes undersaturated above $110^{\circ} \mathrm{C}$, also at the same time when anhydrite becomes supersaturated.

\subsection{Site 1036}

Only two temperature measurements were made at this site in Hole $1036 \mathrm{C}$ at 16 and 35 mbsf. These data show that the temperature gradient is not linear. Temperatures below $35 \mathrm{mbsf}$ for Hole 1036C are obtained from an extrapolation of this nonlinear temperature gradient and are therefore quite uncertain. Despite these restrictions, our results (Fig. 10) show some features already observed for other holes: anhydrite is at equilibrium between 100 and $120^{\circ} \mathrm{C}$ in Hole $1036 \mathrm{C}$ and tend to be supersaturated deeper down the hole.

There is no direct temperature measurement for Holes 1036A and B. We have tentatively used the same T gradient as for Hole $1036 \mathrm{C}$, but the results displayed in Figure 10 are too uncertain to be discussed. 


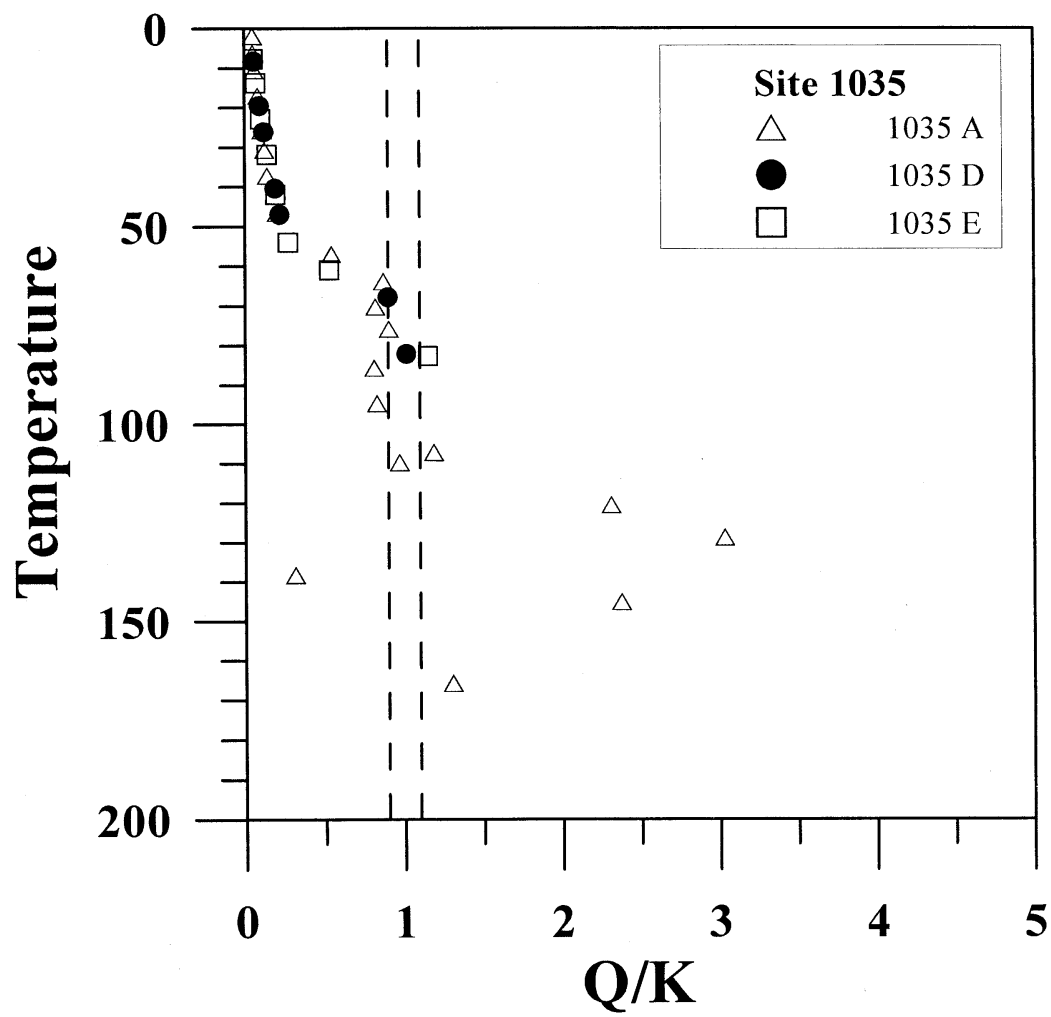

Fig. 7. The anhydrite saturation index for the Site 1035 porewaters versus the in-situ temperature.

\section{DISCUSSION}

One of the first questions to address in water-rock interaction modeling is to know whether calculated departures from equilibrium (indicated by saturation indices different from 1) are real phenomena associated to the dynamics of the system under study, or only model artifacts. This outlines the importance of model validation, a step in which data independent from those used in the model construction are used to test model predictions. Here we have supplemented this step by showing the good agreement between calculated and measured temperatures of anhydrite formation in standard seawater. Also the performance of the thermodynamic model is illustrated by saturation indices scattered around the equilibrium value of 1 in Figures 4 to 10 .

First of all, our results indicate that there is no equilibration of the cores at the shipboard temperature and pressure. At the in situ temperatures and pressures, anhydrite reaches saturation when the temperature is at least $70^{\circ} \mathrm{C}$ (for a pressure of about 260 bars). Saturation indices calculated for the in situ $\mathrm{T}$ and $\mathrm{P}$ indicate anhydrite supersaturation for porewaters collected at depths corresponding to temperatures above $110-120^{\circ} \mathrm{C}$. This supersaturation is an artifact consistent with the redissolution of anhydrite (the presence of which is common in these hydrothermal environments) when the cores are cooled during core retrieval. Anhydrite dissolution increases the porewater calcium and sulfate contents which then lead to elevated values of the anhydrite saturation index when calculated for in situ temperatures and pressures. The fact that this anhydrite dissolution occurs around $110-120^{\circ} \mathrm{C}$ while it is at equilibrium between 70 and $110^{\circ} \mathrm{C}$ is puzzling. It cannot be due to boiling when porewaters decompress: boiling is avoided for safety reasons during operations by vigorous pumping of cool drilling fluids (usually surface seawater the temperature of which is $12^{\circ} \mathrm{C}$ at Juan de Fuca). Also boiling would induce anomalously high porewater salinities that would be readily detected in the porewater salinity profiles. To our knowledge, this has not been reported for any of the holes. We tentatively propose that anhydrite dissolution is fast enough only at high temperature (i.e., above $110^{\circ} \mathrm{C}$ ). At lower temperatures (i.e., for the upper sections of the boreholes), even if present in the sediment, it does not have the time to dissolve before the sampling of porewaters (usually within at most a couple of hours after the cores are lifted on board).

In a work using the same model as the present one to analyze barite stability in the water column of the world's ocean, Monnin et al. (1999) have found that the Pacific Ocean waters are at equilibrium with barite at depths between about $2000 \mathrm{~m}$ and $4000 \mathrm{~m}$. Paytan and Kastner (1996) have shown that the Ba content of core top porewaters is larger than that of the deep ocean water, suggesting supersaturation if it is assumed that barite is at equilibrium in the water column at these depths. On another depth scale within the sediment, Monnin et al. (2000) have shown that porewaters collected within the first $20 \mathrm{~m}$ or so of sediments of the Eastern flank of the Juan de Fuca ridge are indeed supersaturated with respect to barite. This supersaturation decreases with depth to the point where equilibrium with barite is reached. In this work, we also observe that porewaters are supersaturated with respect to barium sulfate (barite) in the 


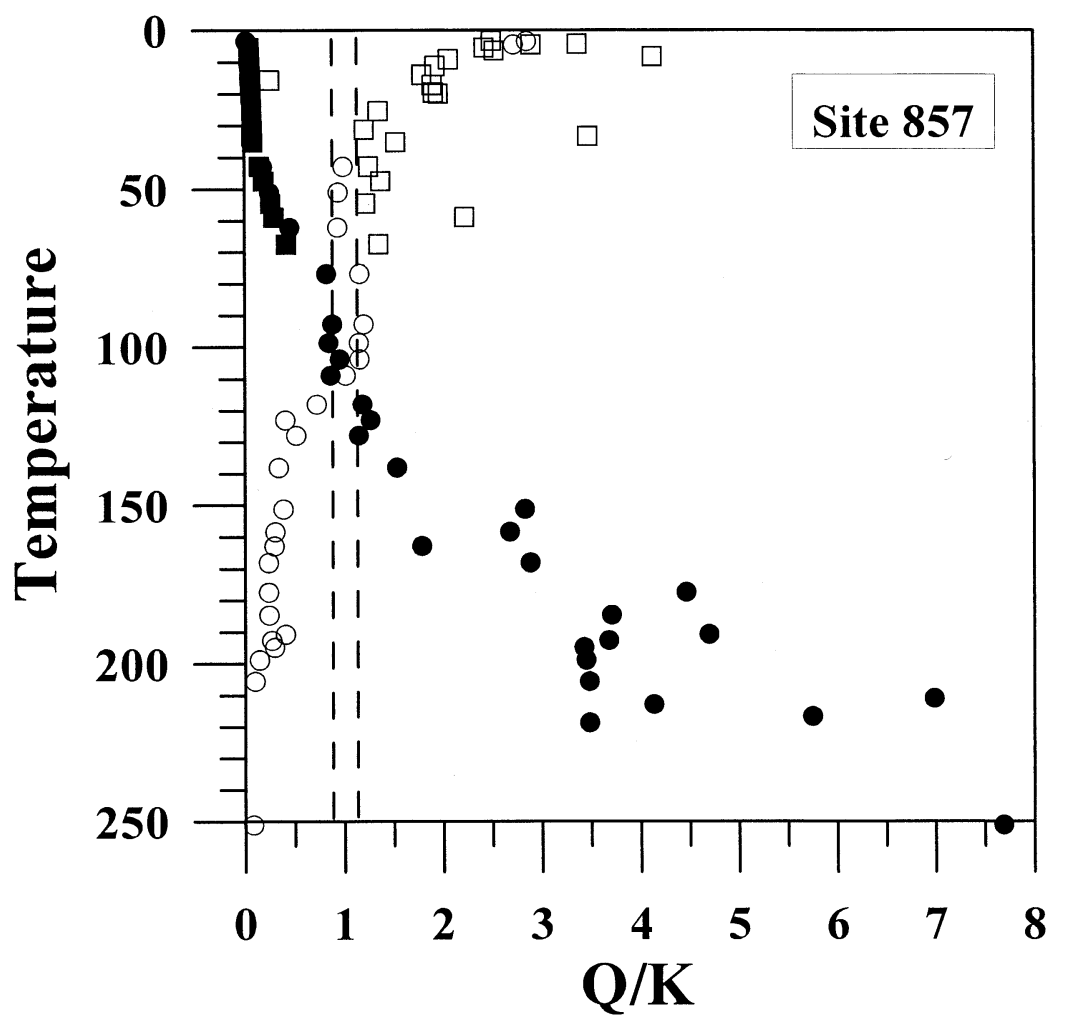

Fig. 8. The anhydrite (filled symbols) and barite (open symbols) saturation indices for porewaters of ODP Site 857 versus the in-situ temperature (squares: Hole 857A; circles: Hole 857C).

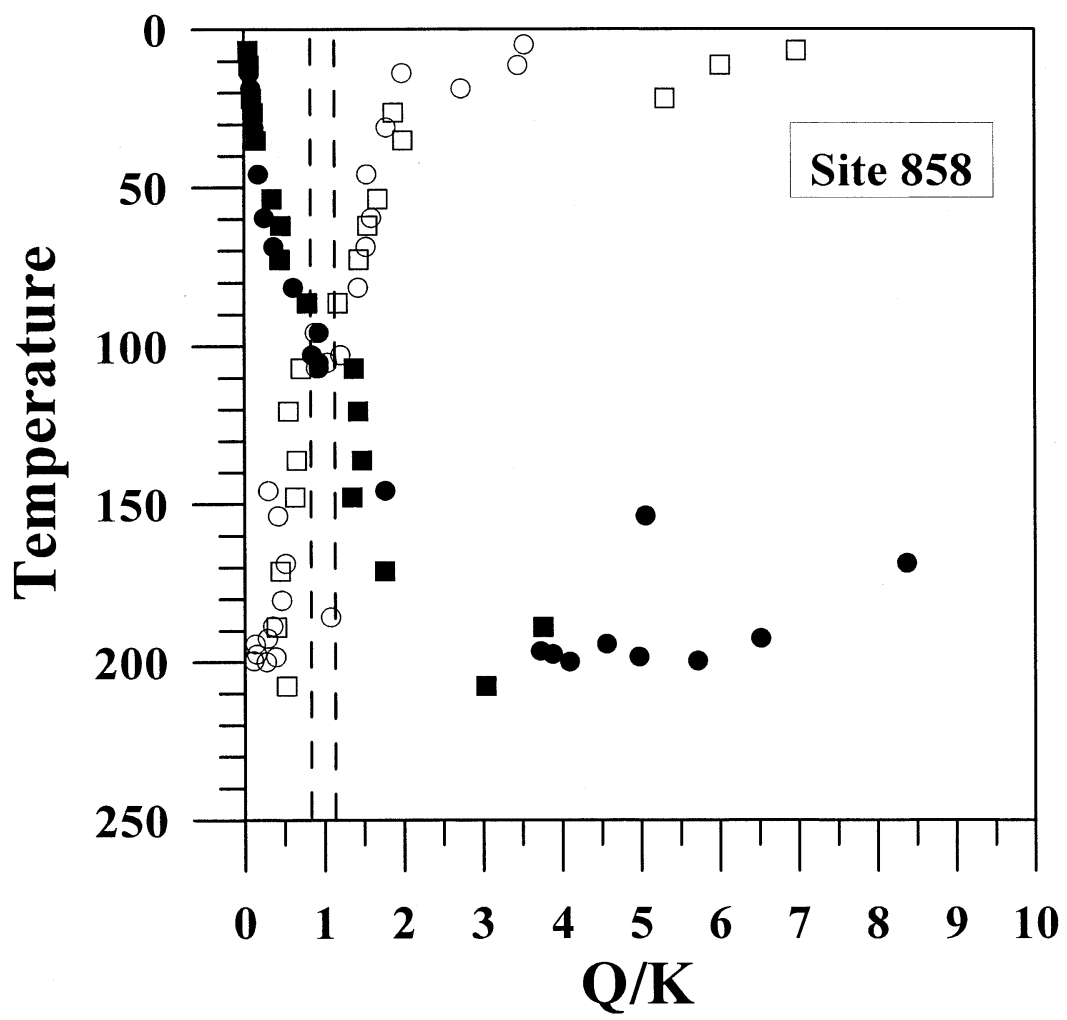

Fig. 9. The anhydrite (filled symbols) and barite (open symbols) saturation indices for porewaters of ODP Site 858 versus the in-situ temperature (circles: Hole 858A; squares: Hole 858C). 


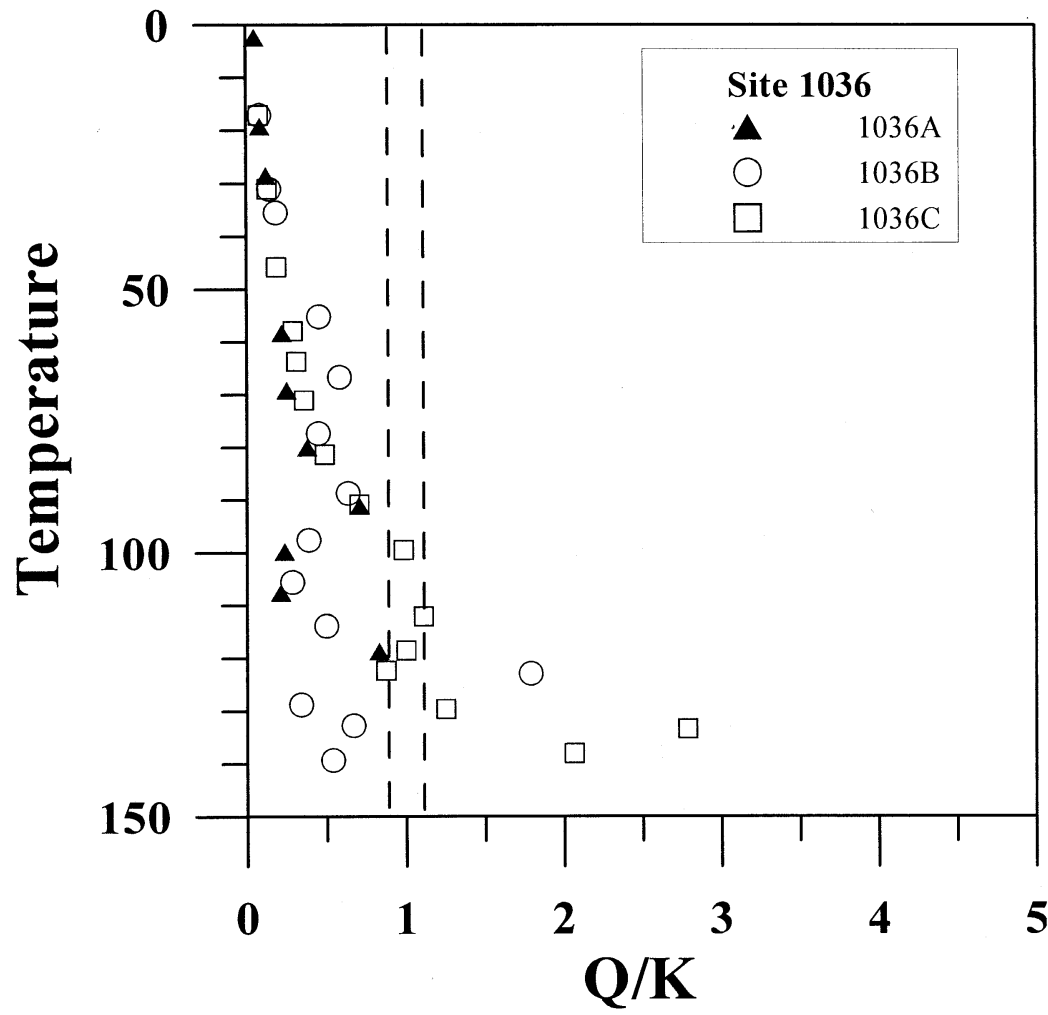

Fig. 10. The anhydrite saturation index for ODP Site 1036 porewaters versus the in-situ temperature.

upper parts of the boreholes with a tendency toward equilibrium as indicated by decreasing barite saturation indices with depth. When anhydrite becomes supersaturated, barite becomes undersaturated. This undersaturation within this temperature range at the in situ pressure is also an artifact. It is a consequence of anhydrite redissolution: the increase of the porewater sulfate content induces barite precipitation (this is called the common ion effect). The barium depleted solution then appears undersaturated at the borehole in situ temperature and pressure.

Finally it seems likely that, if it was not hidden by the sampling artifact, anhydrite would remain at equilibrium, after it reaches saturation, with the porewaters at the in situ temperatures and pressures throughout the sediment column of the high temperature ridge axis sediments studied in this work. Our model of the Na-K-Ca-Mg-Cl-SO $\mathrm{S}_{4}-\mathrm{H}_{2} \mathrm{O}$ system could then be used to recalculate, if necessary, the porewater calcium and sulfate profiles from the hypothesis of anhydrite equilibrium.

\section{CONCLUSIONS}

1. It is commonly accepted that standard seawater becomes saturated with respect to anhydrite at a temperature of $150^{\circ} \mathrm{C}$, as shown experimentally by Bischoff and Seyfried (1978). Such an assumption overlooks the effect of pressure. The Bischoff and Seyfried (1978) experiments have been carried out for a pressure of 500 bars. We show that reducing the pressure from 500 bars to 20 bars lowers the equilibrium temperature of anhydrite in standard seawater from 147 to $117^{\circ} \mathrm{C}$.
2. We have calculated the barite and anhydrite saturation indices for the in situ temperatures and pressures, from the composition of porewaters collected at ODP Sites 855, 856, 857, 858, 1035 and 1036 during ODP Legs 139 and 169 (Juan de Fuca and Gorda ridges, NE Pacific). Calculated saturation indices for porewater samples collected at depths corresponding to temperatures between $70^{\circ}$ and $110-120^{\circ} \mathrm{C}$ at an in situ pressure of about 260 bars yield equilibrium values for anhydrite and barite. Saturation indices of samples collected at depths where the temperature exceeds $110-120^{\circ} \mathrm{C}$, however, yield values indicating supersaturation with respect to anhydrite and undersaturation with respect to barite. This result is consistent with the redissolution of anhydrite during cooling, leading to the well documented sampling artifact affecting porewater compositions in high temperature marine sediments: anhydrite dissolution increases the porewater sulfate content, which in turn induces a loss of barium from solution through barite precipitation (the common ion effect). We postulate that this redissolution occurs in sediment samples for which the in situ temperature exceeds $110-120^{\circ} \mathrm{C}$ : below this limit anhydrite remains at equilibrium or does not have time to significantly dissolve before porewaters are sampled.

3. In accordance with what has already been observed (Monnin et al., 1999, 2000), porewaters are supersaturated with respect to barite in the upper section of the sediment column. This supersaturation decreases with depth to the point where equilibrium is reached: barite is at equilibrium with the 
porewaters in the temperature range where anhydrite is also at equilibrium. Above the temperature where anhydrite dissolution occurs $\left(110-120^{\circ} \mathrm{C}\right)$, porewaters appear undersaturated with respect to barite at the in situ $\mathrm{T}$ and $\mathrm{P}$ because of the barium loss at low temperature during sampling. This undersaturation is also an artifact: the barium loss is due to the increase in the porewater sulfate content following anhydrite dissolution during core cooling.

Acknowledgments-We acknowledge the support of S. Balleur by Schlumberger-Clamart. Many thanks are due to Geoff Wheat for his comments and for his interest at an early stage of this work, to Joris Gieskes and to the two anonymous reviewers for their suggestions leading to substantial improvements of the manuscript.

Associate editor: L. Walter

\section{REFERENCES}

Anschutz P., Blanc G., Monnin C., and Boulègue J. (2000) Geochemical dynamics of the Atlantis II Deep (Red Sea): II. Composition of metalliferous sediment pore waters. Geochim. Cosmochim. Acta 64(23), 3995-4006.

Baker P. A. and Bloomer S. H. (1988) The origin of celestite in deep-sea carbonate sediments. Geochim. Cosmochim. Acta 52, 335339.

Bischoff J. L. and Seyfried W. E. (1978) Hydrothermal chemistry of seawater from $25^{\circ}$ to $350^{\circ} \mathrm{C}$. Am. J. Sci. 278, 838-860.

Blount C. W. (1977) Barite solubilities and thermodynamic quantities up to $300^{\circ} \mathrm{C}$ and 1400 bars. Am. Min. 62, 942-957.

Chang L. L. Y., Howie R. A., and Sussman J. (1996) Rock Forming Minerals: Non-Silicates, Sulfates, Carbonates, Halides and Phosphates. Longman Group, Harlow, UK.

Davis E. E, Villinger H (1992) Tectonic and thermal structure of the Middle Valley sedimented rift, northern Juan de Fuca Ridge. In Proc. ODP, Init. Repts., 139 (ed. E. E. Davis, M. J. Mottl, A. T. Fisher et al.), College Station TX (Ocean Drilling Program), pp. 9-42.

Davis E. E, Mottl M. J, Fisher A. T., Baker P. A., Becker K., Boni M., Boulegue J. J., Brunner C. A., Duckworth R. C., Franklin J. M., Goodfellow W. D., Groeschel-Becker H. M., Kinoshita M., Konyukhov B. A., Koerner U., Krasnov S. G., Langseth M. G., Mao S. I., Marchig V., Marumo K., Oda H., Rigsby C. A., Simoneit B. R. T., Stakes D. S., Villinger H. W., Wheat C. G., Whelan J. K., and Zierenberg R. A. (1992) Proc. ODP, Init. Repts., 139, College Station TX (Ocean Drilling Program).

Dehairs F., Chesselet R., and Jedwab J. (1980) Discrete suspended particles of barite and the barium cycle in the open ocean. Earth Planet. Sci. Lett. 49, 528-550.

Fouquet Y, Zieremberg R. A, Miller D. J., Bahr J. M., Baker P. A., Bjerkgarden T., Brunner C. A., Duckworth R. C., Gable R., Gleskes J. M., Goodfellow W. D., Groeschel-Becker H. M., Guerin G., Ishibashi J., Iturrino G. J., James R. H., Lackschewitz K. S., Marquez L. L., Nehlig P., Peter J. M., Rigsby C. A., Simoneit B. B., Schultheiss P. J., Shanks W. C. III, Summit M., Teagle D. A. H., Urbat M., and Zuffa G. G. (1998) Proc. ODP, Init. Repts., 169, College Station TX (Ocean Drilling Program).

Gieskes J. M., Simoneit B. R. T., Shanks W. C. III, Goodfellow W. D., James R. H., Baker P., and Ishibashi J. (2002) Geochemistry of fluid phases and sediments: Relevance to hydrothermal circulation in Middle Valley, ODP Leg 139 and 169. Appl. Geochem. 17, 13811399.

Greenberg J. P. and Moller N. (1989) The prediction of mineral solubilities in natural waters: A chemical equilibrium model for the system to high concentration from 0 to $250^{\circ} \mathrm{C}$. Geochim. Cosmochim. Acta 53, 2503-2518.

Hanor J. S. (2000) Barite-celestine geochemistry and environments of formation. In Sulfate Minerals: Crystallography, Geochemistry and Environmental Significance (ed. C. N. Alpers, J. L. Jambor, and D. K. Nordstrom). Rev. Min. Geochem. 40, 193-276.
Harvie C., Moller N., and Weare J. H. (1984) The prediction of mineral solubilities in natural waters: The system to high ionic strengths at $25^{\circ} \mathrm{C}$. Geochim. Cosmochim. Acta. 48, 723-751.

Kurnosov V., Mrdmaa I., Rosanova T., Kashintsev G., Eroshchev-Shak V., and Krasnov S. (1994) Mineralogy of hydrothermally altered sediments and igneous rocks at Sites 856-858, Middle Valley, Juan de Fuca Ridge, Leg 139. In Proc. ODP, Sci. Results, 139 (ed. M. J. Mottl, E. E. Davis, A. T. Fisher, and J. F. Slack), College Station, TX (Ocean Drilling Program), pp. 113-132.

McManus J., Berelson W. M., Klinkhammer G. P., Kilgore T. E., and Hammond D. E. (1994) Remobilization of barium in continental margin sediments. Geochim. Cosmochim. Acta 58, 4899-4907.

Moller N. (1988) The prediction of mineral solubilities in natural waters: A chemical equilibrium model for the system to high temperature and concentration. Geochim. Cosmochim. Acta 52, 821837.

Monnin C. (1989) An ion interaction model for the volumetric properties of natural waters: Density of the solution and partial molal volumes of electrolytes to high concentration at $25^{\circ} \mathrm{C}$. Geochim. Cosmochim. Acta 53, 1177-1188.

Monnin C. (1990) The influence of pressure on the activity coefficients of the solutes and on the solubility of minerals in the system $\mathrm{Na}-\mathrm{Ca}-\mathrm{Cl}-\mathrm{SO}_{4}-\mathrm{H}_{2} \mathrm{O}$ to $200^{\circ} \mathrm{C}$ and $1 \mathrm{kbar}$, and to high $\mathrm{NaCl}$ concentration. Geochim. Cosmochim. Acta 54, 3265-3282.

Monnin C. (1999) A thermodynamic model for the solubility of barite and celestite in electrolyte solutions and seawater from 0 to $200^{\circ} \mathrm{C}$ and to 1 kbar. Chem. Geol. 153, 187-209.

Monnin C. and Ramboz C. (1996) The anhydrite saturation index of the ponded brines and sediment pore waters of the Red Sea deeps. Chem. Geol. 127, 141-159.

Monnin C., Jeandel C., Dehairs F., and Cattaldo T. (1999) The barite saturation state of the world's ocean. Mar. Chem. 65, 253-261.

Monnin C., Wheat C. G, Dupre B., Elderfield H., and Mottl M. M. (2001) Barium geochemistry in sediment porewaters and formation waters of the oceanic crust on eastern flank of the Juan de Fuca ridge (ODP Leg 168). Geochemistry, Geophysics, Geosystems, paper 2000GC000073 (http://www.g-cubed.org).

Mottl M. J., Davis E. E., Fisher A. T., and Slack J. F.(1992) Proc. ODP, Sci. Results, 139, College Station, TX (Ocean Drilling Program).

Mottl M. J., Wheat C. G., and Boulègue J.(1994) Timing of ore deposition and sill intrusion at Site 856: Evidence from stratigraphy, alteration and sediment porewater composition. In Proc. ODP, Sci. Results, 139 (1992) (ed. M. J. Mottl, E. E. Davis, A. T. Fisher, and J. F. Slack). College Station, TX (Ocean Drilling Program), pp. 679-694.

Pabalan R. and Pitzer K. S. (1987) Thermodynamics of concentrated electrolyte mixtures and the prediction of mineral solubilities to high temperature for mixtures in the system Na-K-Mg-Cl- $-\mathrm{SO}_{4}-\mathrm{H}_{2} \mathrm{O}$. Geochim. Cosmochim. Acta 51, 2429-2443.

Paytan A. and Kastner M. (1996) Benthic Ba fluxes in the central Equatorial Pacific: Implications for the oceanic Ba cycle. Earth Planet. Sci. Lett. 142, 439-450.

Sleep N. H. (1991) Hydrothermal circulation, anhydrite precipitation and thermal structure at ridge axes. J. Geophys. Res. 96(B2), 23752387.

Torres M. E., Brumsack H. J., Bohrmann G., and Emeis K. C. (1996) Barite fronts in continental margin sediments: A new look at barium remobilisation in the zone of sulfate reduction and formation of heavy barites in diagenetic fronts. Chem. Geol. 127, 125-139.

Wheat C. G, Mottl M. M (1994) Data report: Trace metal composition of pore water from Site 855 through 858. In Proc. ODP, Sci. Results, 139 (ed. M. J. Mottl, E. E. Davis, A. T. Fisher, and J. F. Slack), College Station, TX (Ocean Drilling Program), pp. 749-758.

Wheat C. G, Boulègue J., and Mottl M. J.(1994) A technique for obtaining pore water composition from indurated and hydrothermally altered sediment and basalt: The ground rock interstitial normative determination (GRIND). In Proc. ODP, Sci. Results, 139 (ed. M. J. Mottl, E. E. Davis, A. T. Fisher, and J. F. Slack), College Station, TX (Ocean Drilling Program), pp. 429-440.

Weare J. (1987). Models of mineral solubility in concentrated brines with application to field observation. In Thermodynamic Modeling of Geological Material: Minerals, Fluids and Melts (ed. I. S. E. Carmichael and H. P. Eugster), pp 143-174, Rev. Miner. 17, 499. 